\title{
PENINGKATAN PRODUKTIVITAS KAMBING DI KELOMPOK TERNAK KAMBING KECAMATAN CEMPAKA KOTA BANJARBARU KALIMANTAN SELATAN
}

\author{
Tintin Rostini $^{(1)}$, Irwan Zakir ${ }^{(1)}$, dan Rizqi Elmuna Hidayah ${ }^{(2)}$ \\ ${ }^{1)}$ Fakultas Pertanian, Jurusan Peternakan, Universitas Islam Kalimantan MAB \\ ${ }^{2)}$ Fakultas Teknologi Informasi, Universitas Islam Kalimantan MAB \\ Email : tintin_rostini@yahoo.com
}

\begin{abstract}
ABSTRAK
Tujuan kegiatan pengabdian ini adalah untuk meningkatkan produktivitas usaha ternak kambing sehingga dapat meningkatkan pendapatan peternak. Solusi yang ditawarkan dalam kegiatan ini adalah Peningkatan pengetahuan dan keterampilan serta penguasaan metode/teknik pengolahan bahan pakan local. Dengan cara Pelatihan teoritis (metode kelas) teknik pengolahan pakan ternak dan pemeliharaan kambing potong pada 25 orang peternak kambingsedangkan penerapan teknologi pengolahan pakan pada ternak kambing dengan menggunakan kambing kacang sebanyak 12 ekor. Parameter yang diukur tingkat pengetahuan peternak dan peningkatan produktivitas kambing. Hasil dari kegiatan terjadi peningkatan sebesar $70-90 \%$ peningkatan ketrampilan dan pengetahuan peternak, adanya peningkatan pertambahan bobot badan kambing. bahwa dengan adanya kegiatan di Kecamatan Cempaka ini masyarakat berasa terbantu dengan paket teknologi yang diberikan.
\end{abstract}

Kata Kunci : hay, kambing, nutrisi, pakan

\section{PENDAHULUAN}

Masyarakat di Kalimantan

Selatan banyak yang berusaha di bidang peternakan baik ternak rumiansia (sapi, kambing dan kerbau) juga ternak Unggas (itik, ayam kampung dan ayam ras). Masalah yang dihadapi oleh peternak adalah ketersedian pakan ternak karena ketersediaan lahan-lahan hijauan pakan sudah bergeser menjadi perkebunan kelapa sawit, banyak masyarakat yang tergolong usaha kecil dan menengah yang gulung tikar akibat ketersedian pakan yang kurang sehingga harga menjadi melonjak.

Ternak kambing merupakan ternak unggulan kedua setelah sapi dalam penyediaan swasembada daging (Rostini,2014). Namun peningkatan pertumbuhan sangat rendah yaitu berkisar hanya $3 \%$ dibandingkan pertumbuhan sapi mencapai $6 \%$ (Dinas Peternakan Kalsel, 2016), hal ini dikarenakan pemeliharaan kambing masih secara tradisional disekitar kandang dan sistem cut and cury menggunakan rumput lapangan dan hijauan yang nilai gizinya rendah. Pakan yang unggul memerlukan 
biaya yang sangat besar dalam usaha peternakan yaitu sekitar 70\% dari total biaya produksi. Oleh karena itu, sangat diperlukan ketersediaan pakan yang murah, agar usaha yang dilakukan oleh masyarakat dapat terus berkesinambungan dan dapat meningkatkan produktivitas ternak.

Mitra yang dilibatkan pada Ipteks bagi masyarakat (IbM) berdomisili di Kelurahan yang berbeda yakni Kelompok Sumber Jaya berdomisili di Kelurahan/desa Cempaka Kecamatan Cempaka Kota Banjarbaru Kalimantan Selatan. Jarak antara Pemerintahan Kecamatan Cempaka $\pm 10 \mathrm{~km}$ dengan pusat Kota Banjarbaru dan $\pm 35 \mathrm{~km}$ dari Provinsi Kalimantan Selatan dengan kondisi jalan yang baik dan dapat ditempuh dengan kendaraan. Luas wilayah Kelurahan/desa Cempaka $\pm 1.876 \mathrm{Ha}$ dengan posisi terletak pada bagian timur Kecamatan Cempaka.

Usaha ternak kambing merupakan usaha yang paling diminati oleh anggota kelompok, karena usaha ini mudah dioperasikan dengan lama pemeliharaan 6-7 bulan sudah bisa menghasilkan cempe dan bila digemukkan hanya memerlukan waktu 3-4 bln tergantung dari umur kambing yang dipelihara.
Namun demikian dalam menjalankan usaha beternak kambing potong cukup banyak kendala yang dihadapi oleh anggota-anggota tani tersebut terutama dalam hal penyediaan pakan. Hal ini disebabkan karena lahan tempat pemeliharaan berkurang karena sudah beralih fungsi menjadi perumahan, selain itu masih berupa tanah gambut dengan kadar asam sangat tinggi, sehingga anggota kelompok Sumberr Jaya dan Ternak Mandiri mengalami kesulitan dalam penyediaan hijauan yang akhirnya berimbas pada produktivitas khususnya pertumbuhan kambing Rendahnya produktivitas kambing ini salah satunyanya disebabkan karena skill peternak sangat terbatas khususnya dalam hal pengolahan pakan pakan bagi ternak kambing yang mereka pelihara, sehingga sebagian besar pakan anggota kelompok tani tersebut masih sangat tergantung dengan ketersediaan pakan di alam.

Tujuan dilakukan kegiatan pengabdian ini adalah untuk meningkatkan produktivitas usaha ternak kambing sehingga dapat meningkatkan pendapatan peternak 


\section{METODE PELAKSANAAN}

\section{Metode Pelakasaan}

Metode yang dilaksanapan dalam kegiatan pengabdian ini terdiri dari beberapa tahap yaitu : Tahap pertama Persiapan program kegiatan IbM dengan konsoolidasi baik dengan tim pelaksana maupun dengan kelompok mitra. Tahap kedua adalah : Pengurusan izin baik pada uuniversitas maupun dinas peternakan dan penyuluh pertanian dalam melaksanakan kegiatan pengabdian ini. Tahap ketiga adalah:: Pelaksanaan program kegiatan,

Pelaksanaan :

1) Pelatihan terstruktur bagi anggota kelompok sasaran untuk meningkatkan pemahaman dan skill beternak kambing utamanya adaptasi teknologi penggunaan dan pengolahan pakan. Landasan keilmuan lain juga diberikan untuk lebih menyempurnakan wawasan keilmuan peternak. Modul pelatihan yang disiapkan adalah tatalaksana pemeliharaan kambingi potong, tatalaksana pemberian pakan, tatalaksana kandang, tatalaksana bibit dan pencegahan penyakit

2) Demonstrasi pembuatan pakan fermentasi, Metode pembuatan pakan ternak dalam bentuk silase ransum komplit, dimulai dengan pengumpulan pakan untuk selanjutnya dilakukan pencampuran dengan bahan baku pakan lainnya (jagung kuning, dedak, sagu(paya), ampas tahu, rumput gajah dan rumput sertaria, jerami padi dan jerami jagung, Urea, tetes dll), sesuai dengan kebutuhan nutirisi kambing lokal umur satu tahun. Kebutuhan nutrisi kambing merujuk pada NRC (2004), sedangkan formulasi ransum menggunakan soft ware Feed Mania. Campuran bahan kemudian dimasukkan ke dalam silo, dipadatkan dan ditutup untuk mendapatkan suasana anaerob selama 2-3 minggu.

\section{HASIL DAN PEMBAHASAN}

Peningkatan Keterampilan peternak

$$
\text { Peningkatan }
$$

keterampilan

peternak dalampengetahuan bahan dan teknologi pengawetan pakan dilakukan melalui Kegiatan Penyuluhan menggunakan model partisipatif (PRA). Metode PRA dipilih karena dapat memberikan akan gambaran keaadaan/kebutuhan yang diinginkan peternak tentang hal-hal pakan ternak, baik jenis dan teknologi pengolahan, adopsi teknologi yang diinginkan serta berbagai masalah dan kendala yang dirasakan peternak mitra. Hal ini akan mempercepat adopsi paket teknologi 
yang akan disampaikan dan harapan untuk ditindak lanjuti di masa akan datang. Kegiatan ini dilaksanakan di awali dengan pre tes untuk mengetahui kemampuan awal (pre test) sebelum kegiatan dilakukan, dimana peserta kegiatan yang berjumlah 25 orang, meliputi peserta berasal dari peternak mitra. Setelah kegiatan selesai dilakukan evaluasi pemahaman peserta (post test) terhadap beberapa aspek teknis dan keterampilan peserta kegiatan terhadap materi yang disampaikan oleh nara sumber utama kegiatan.

Suasana kegiatan penyuluhan yang dilakukan bersama peserta kegiatan IbM disajikan pada Gambar 1 di bawah ini.
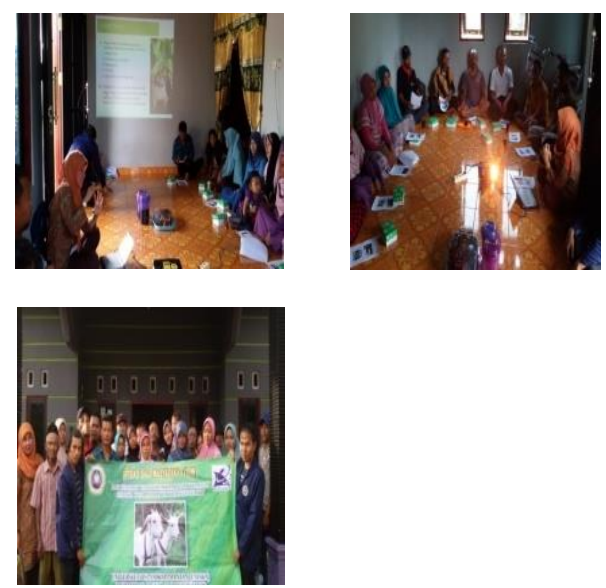

Gambar : penyuluhan pada kelompok mitra

Berdasarkan hasil tabulasi kegiatan awal (pre test) dan kegiatan akhir (post test) yang dilaksanakan pada kegiatan penyuluhan, diperoleh hasil pada semua aspek yang diamati terjadi kemampuan baik teknis dan keterampilan pengolahan pakan ternak dalam budidaya ternak kambing, disajikan pada Tabel 2.

Tabel 2. Teknik dan Keterampilan Budidaya Beternak Kambing

\begin{tabular}{|c|c|c|c|}
\hline \multirow{2}{*}{ r } & \multirow[t]{2}{*}{ Uraian } & \multicolumn{2}{|c|}{ Prosentase $(\%)$} \\
\hline & & $\begin{array}{l}\text { Sebelu } \\
\text { m IbM }\end{array}$ & Setelah IbM \\
\hline 1 & $\begin{array}{l}\text { Pengetahuan } \\
\text { tentang jenis- } \\
\text { jenis pakan } \\
\text { ternak } \\
\text { ruminansia }\end{array}$ & $10-25$ & $70-85$ \\
\hline 2 & $\begin{array}{l}\text { Pemahaman } \\
\text { pakan } \\
\text { berkualitas }\end{array}$ & $10-25$ & $70-85$ \\
\hline 3 & $\begin{array}{l}\text { Pemahaman } \\
\text { tenik } \\
\text { pengolahan } \\
\text { pakan }\end{array}$ & $10-15$ & $65-80$ \\
\hline 4 & $\begin{array}{l}\text { Pengetahuan } \\
\text { tentang jenis } \\
\text { kebersihan } \\
\text { kandang } \\
\text { ternak yang } \\
\text { aman bagi } \\
\text { kambing }\end{array}$ & $30-35$ & $70-80$ \\
\hline 5 & $\begin{array}{l}\text { Teknis } \\
\text { pembuatan } \\
\text { hay }\end{array}$ & $15-20$ & $60-75$ \\
\hline 6 & $\begin{array}{l}\text { Teknis pakan } \\
\text { fermentasi }\end{array}$ & $0-5$ & $60-75$ \\
\hline 7 & $\begin{array}{l}\text { Teknik } \\
\text { pembuatan } \\
\text { wafer hiajuan } \\
\text { komplit }\end{array}$ & $0-5$ & $60-75$ \\
\hline 8 & $\begin{array}{l}\text { Teknik } \\
\text { penyimpakan } \\
\text { pakan }\end{array}$ & $0-5$ & $65-75$ \\
\hline 9 & $\begin{array}{l}\text { Pemahanan } \\
\text { tentang } \\
\text { pemeliharaan }\end{array}$ & $45-60$ & $70-80$ \\
\hline
\end{tabular}




\begin{tabular}{|r|l|l|l|}
\hline & $\begin{array}{l}\text { ternak } \\
\text { kambing }\end{array}$ & & \\
\hline 1 & Teknik & $40-60$ & $70-85$ \\
0 & $\begin{array}{l}\text { Pemberian } \\
\text { pakan pada } \\
\text { ternak } \\
\text { kambing }\end{array}$ & & \\
\hline
\end{tabular}

Keterangan : Nilai \% dari tabulasi nilai 25 peserta pelatihan

(pre test \& post test)

Hasil akhir yang baik dari tahap ini adalah adanya peningkatan pemahaman dari pengetahuan dan skill mereka setelah pelatihan, ditunjukkan dengan meningkatnya nilai post test yang diberikan di akhir kegiatan penyuluhan yang dilaksanakan dari $60-65 \%$ meningkat menjadi $70-90 \%$. Indikator keberhasilan kegiatan penyuluhan juga dapat dilihat dari tertibnya peserta dalam hal ketepatan waktu kehadiran mencapai 90 - $100 \%$, sedangkan respons peserta yang tinggi untuk memahami dan mendalami teknologi pengawetan dan pengolahan pakan yang diintroduksi juga terlihat melalui indikator keaktifan dalam kegiatan diskusi saat penyuluhan (90$100 \%$ ), keaktifan peserta dalam mengemukakan ide, gagasan, dan pertanyaan seputar proses pengeringan dendeng ( $80-90 \%)$.

\section{Teknologi Pengawetan}

Demontrasi paket teknologi pengawetan pakan dengan tujuan demo pengawetan adalah memberi bekal teknis dan keterampilan peternak sebagai peserta kegiatan dalam mengantisipasi panen rumput yang melimpah saat musim hujan, untuk dibuat silase dan disimpan dalam jangka waktu yang panjang sebagai stok pakan hijauan saat musim kemarau tiba. Dengan demikian diharapkan tidak terjadi kekurangan hijauan saat musim kemarau di kelompok ternak Mitra. Demontrasi pembuatan pembuatan pakan fermentasi pakan yang diintroduksikan sebagai inovasi teknologi dan aplikasi demo pakan serta kajian pakan pada kambing disajikan pada Gambar 2.
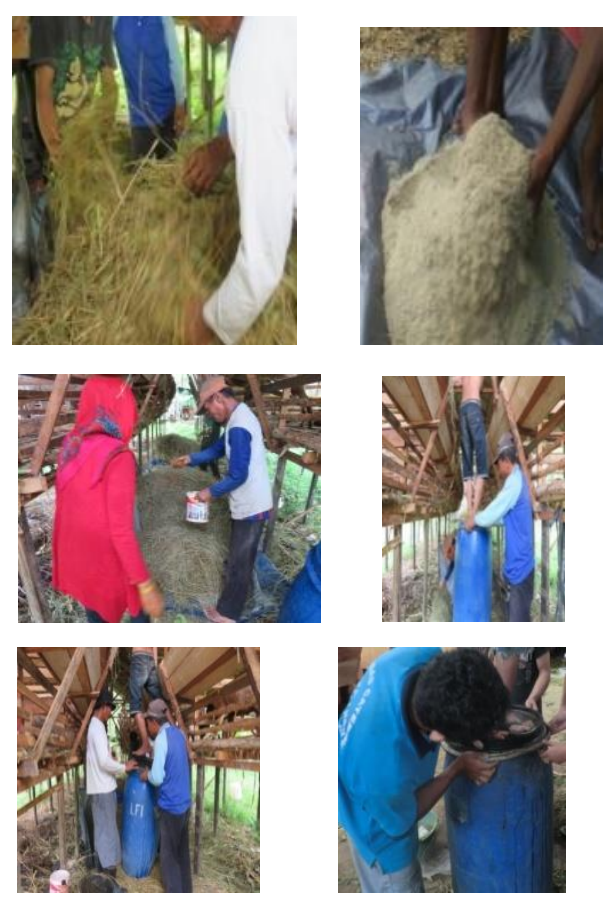

Gambar 2. Demo pembuatan pakan Fermentasi 
Manfaat penggunaan teknologi pengawetan pakan untuk peningkatan produktivitas ternak kambing. Penggunaan pakan fermentasi dapat meningkatkan palatabilitas bagi ternak . Hal ini senada dengan pendapat Rostini (2014). Mengemukakan bahwa pakan fermentasi dapat meningkatkan palatabilitas dan dapat meningkatkan kecernaan pakan pada ternak selain itu tekstur pakan fermentasi lebih lunak sehingga memudahkan ternak untuk mencernanya. .

Aplikasi uji coba pakan fermentasi pada ternak kambing terhadap 12 ekor kambingr milik mitra IbM yaitu peternak mitra menunjukkan hasil peningkatan pertambahan bobot badan ternak sebesar 1,9 kg/ekor selama kegiatan dengan pertambahan bobot badan harian sebesar 75,2 g/ekor/hari. Hasil ini tidak jauh berbeda dengan hasil penelitian Rostini (2014) penggunaan pakan fermentasi pada kambing kacang dapat meningkatkan pertambahan bobot badan sebesar 75130 g/ekor/hari. Hal ini disebabkan hijauan pakan yang digunakan adalah hampir sama yaitu rumput dan legume lokal. Adanya peningkatan ketrampilan peternak dapat meningkatan produktivitas ternak kambing pada kelompok mitra.

Efesiensi penggunaan pakan dalam kajian ini berkisar terjadi peningkatan sebelum kegiatan hanya 0.09 dan setelah kegiatan $\mathrm{IbM}$ terjadi peningkatan sebesar 0.12 .

Tabel 3. Pertambahan bobot badan kambing yang diberi pakan fermentasi

\begin{tabular}{|c|c|c|c|}
\hline No & $\begin{array}{c}\text { Berat badan } \\
\text { kambing }\end{array}$ & $\begin{array}{c}\text { Sebelu } \\
\mathbf{m}\end{array}$ & $\begin{array}{c}\text { Setela } \\
\mathbf{h}\end{array}$ \\
\hline 1 & $\begin{array}{l}\text { Berat badan } \\
\text { awal (kg) }\end{array}$ & 12.9 & 16,9 \\
\hline 2 & $\begin{array}{l}\text { PBBH } \\
(\mathrm{g} / \mathrm{ekor} / \mathrm{hari}) \\
)\end{array}$ & 51,66 & 75,2 \\
\hline 3 & $\begin{array}{l}\text { Efesien } \\
\text { penggunaan } \\
\text { ransum } \\
\text { (EFR ) }\end{array}$ & 0,09 & 0,12 \\
\hline
\end{tabular}

Keterangan : penelitian dilakukan selama 48 hari

$\mathrm{R}$ ataan pertambahan bobot badan dapat dilihat bahwa sebelum ada kegiatan IbM dan setelah ada Ibm menunjukkan hasil yang signifikan, hal ini terjadi karena pakan fermentasi memiliki kandungan nutrisi lebih komplit dibandingkan dengan yang tidak diberikan wafer hijaun, Hal ini senada dengan pendapat Gurbuz dan. Kaplan (2008), bahwa pemberian pakan fermentasi berbasis limbah perkebunan sawit, lumpur sawit, serta perasan buah, 
bungkil inti sawit, molases, urea, dan suplemen mineral vitamin dapat digunakan secara efektif dan memberi pertambahan bobot badan $0,47 \mathrm{~kg}$ per hari untuk domba dan Rostini (2017) penggunaan limbah sawit fermentasi pada penggemukan kambing akan meningkatkan konsumsi pakan, pertambahan bobot badan, efisiensi pakan, persentase karkas dan lemak, serta menurunkan biaya pakan per unit pertambahan bobot badan.

\section{KESIMPULAN}

Berdasarkan uraian kegiatan dan pelaksanaan disimpulkan bahwa dengan adanya kegiatan di Kecamatan Cempaka ini masyarakat berasa terbantu dengan paket teknologi yang diberikan.

Produk IbM menghasilkan pakan fermentasi yang dapat digunakan peternak pada saat musim kemarau dimana rumput sangat sulit didapat sedangkan pada saat musim penghujan melimpah

\section{UCAPAN TERIMA KASIH}

Penulis menyampaikan terima kasih kepada Kementerian, Riset, Teknologi dan Pendidikan Tinggi, Direktur Riset Penelitian dan pengabdian pada Masyarakat melalui hibah Ipteks bagi Masyarakat (IbM) tahun anggaran 2017

\section{DAFTAR PUSTAKA}

Ardiansyah,. Mulyani S, dan Fridarti. 2012. Perubahan Knadungan Nutrisi pelepah dan daun sawit melalui fermentasi dengan kapang Phanerocaete Chrysosporium. Jurnal Litbang : 23(1)

Association of Official Analytical Chemist. 1999. Official Methods of Analysis. Ed ke-16. Washington: AOAC International

Badan Pusat Statistik .2016. Kalimantan Selatan Dalam angka. BPS Kalsel

Gurbuz, Y and M. Kaplan. 2008. Chemical composition, organic matter digestibility, in vitro gas production characteristic and ensiling of sugar beet leaves as alternative feed resource. Journal of Animal and Verterinary Advance .7 (12): 1568 - 1574

NRC (National Research Council). 1981. Nutrient Requirement of Goats: Angora, Dairy, and Meat Goats in Temperate and Tropical Countries. Washington DC: National Academy

Purba A., Ginting S.P. Poeloengan Z, Simanihuruk K, dan Junjungan. 1997. Nilai Nutrisi danManfaat Pelepah Kelapa Sawit sebagai Pakan Ternak. J. Penelitian Kelapa Sawit.5(3): 161 - 170.

Rostini T 2014. Differences in chemical composition and nutrient quality of swamp forage ensiled. International Journal of Biosciences. Vol. 5(12): 145-151 
Rostini T .2014. Produktivitas dan pemanfaatan tumbuhan rawa di Kalimantan Selatan sebagai Hijauan Pakan berkelanjutan. Disertasi Fakultas Pascasarjana Institut Pertanian Bogor.

Rostini T, Zakir I. 2017. Performans produksi, jumlah nematode usus, da, profil metabolik darah kambing yang diberi hijauan rawa

Kalimantan. Jurnal Veteriner No 18(3): 469-477.

Smith, O. B., dan A. A. Adegbola. 1982. Studies on feeding value of agroindustrial by products and thw feeding value of cocoa pods for cattle. J. Tropical Anim. Prod. 1 : 290-295. 